\title{
ANTIBACTERIAL EFFECT OF Herniaria hirsuta, Prunus avium, Rubia tinctorum AND Sempervivum tectorum PLANT EXTRACTS ON MULTIPLE ANTIBIOTIC RESISTANT Escherichia coli
}

\author{
EFEITO ANTIBACTERIANO DE Herniaria hirsuta, Prunus avium, Rubia tinctorum $E$ \\ Sempervivum tectorum EXTRATOS VEGETAIS EM VÁRIOS RESISTENTES A \\ ANTIBIÓTICOS Escherichia coli
}

\section{Branislav Radojica ROVČANIN ${ }^{1}$; Tatjana ĆEBOVIĆ ${ }^{2}$; Danijela STEŠEVIĆ ${ }^{3}$; Dušan KEKIĆ ${ }^{4}$; Marko RISTIĆ}

1. Teaching assistant, MD, MSc, Specialist of Biology. Department of human genetics, Faculty of Medicine, University of Belgrade, Belgrade, Serbia; 2. Professor, PhD, Specialist of Biochemistry, Department of biochemistry, Faculty of Medicine, University of Novi Sad, Novi Sad, Serbia; 3. Professor, PhD, Botanist and Plant Physiologist, Department of biology, Faculty of Natural Science and Mathematics, University of Montenegro, Podgorica, Montenegro, 4. MD, MSc, Research assistant in field of Microbiology, Faculty of Medicine, University of Belgrade, Belgrade, Serbia, 5. MSc, Research assistant in field of biochemistry and cell biology, Institute for Molecular Genetics, University of Montpellier 2, Montpellier, France.

\begin{abstract}
The emergence of Escherichia coli isolates with multiple antibiotic resistant phenotypes is considered as a severe health concern. In the present work the antibacterial effect of following plants (Herniaria hirsuta, Prunus avium, Rubia tinctorum and Sempervivum tectorum) was examined. The bacterial model used for estimation of bacterial susceptibility is hospital multiple antibiotic resistant E. coli strain. E. coli ATCC 25922 was used for standard comparison of bacterial susceptibility. Leaves of $H$. hirsuta, $R$. tinctorum and $S$. tectorum as well as petioles of $P$. avium were collected. Ethanol and aqueous extract of each plant was prepared. Antibacterial activity was examined using the agar well diffusion method. Concentration of total phenols, flavonoids, tannins, antocyanins and saponins was determined in plant extracts. E. coli strain is resistant to four unrelated families of antibiotics. Antibacterial effect is proven for all examined plants. Ethanol extracts of $H$. hirsuta and $P$. avium have a more potent antibacterial effect than their aqueous extracts. Aqueous extracts of R. tinctorum and S. tectorum have higher antibacterial potential than theirs ethanol extracts. Examined plant extracts represent good candidates for more extensive research in view of their application in the treatment of multiple antibiotic resistant E.coli strains.
\end{abstract} compounds.

KEYWORDS: Antibiotic resistance. Escherichia coli. Traditional medicine. Plant extracts. Antibacterial

\section{INTRODUCTION}

Antibiotic resistance in pathogenic bacteria is a serious public health issue. The emergence of Escherichia coli (E.coli) isolates with multiple antibiotic resistance (MAR) phenotypes, involving co-resistance to four or more unrelated families of antibiotics, has been previously reported and is considered as a severe health concern (VENTURINI et al., 2010). Though usually harmless, various $E$. coli strains have genetic determinants which make them pathogenic for both humans and animals. $E$. coli can be responsible for enteric and diarrhoeal diseases, urinary tract infections, sepsis and meningitis (CHESNOKOVA et al. 1999). Since 2003, E. coli strains producing extended spectrum $\beta$-lactamases (ESBLs), particularly CTX-M-15 (cluster of cefotaxime resistant $\beta$-lactamases) have become increasingly common according to the Health Protection Agency. ESBLs are enzymes capable of hydrolysing penicillins, broad-spectrum cephalosporins and monobactams, which pose unique challenges to clinical microbiologists, clinicians, infection control professionals and antibacterial-discovery scientists. Subsequently, producer strains are often resistant to fluoroquinolones and trimethoprim. The population of $E$. coli with CTX-M-15 enzymes is partly clonal and a specific strain, "A", is particularly widespread, being dominant in some areas. Isolates of strain A that also possess an acquired AmpC $\beta$ lactamase have recently been reported (WOODFORD et al. 2007). Uropathogenic $E$. coli (UPEC) is the most common cause of community- and hospital-acquired urinary tract infections (UTIs). Isolates from uncomplicated community-acquired UTIs express a variety of virulence traits that promote the efficient colonization of the urinary tract. There are evidences that these strains are accumulating substantial additional resistances with time. Uropathogenic E. coli is the primary causative agent for urinary tract infections (UTIs) and it has been presumed to be a predominantly extracellular 
pathogen. This concept has been challenged by recent studies demonstrating the ability of UPEC to invade bladder epithelial cells (TRINCHINA, 2003). There are numerous plant remedies which are used for treatment of $E$. coli based urinary infections. Some of them include preparations based on Arctostaphylos uva-ursi L. (pinemat manzanita), Armoracia rusticana P.Gaertn., B.Mey. \& Scherb. (horseradish), Equisetum arvense L. (field horsetail), Solidago virgaurea L. (European goldenrod), Vaccinium macrocarpon A. (large cranberry) etc (WILLFORT, 2009; KOJIC et al. 1998). Despite modern pharmacological approach to treatment of E. coli related bladder infections, in nowhere days people from many parts of Serbia and other Balkan countries are using herbs and traditional remedies for this purpose. Some of the most used plants for treatment of bladder infections in rural parts are: Herniaria hirsuta L. (hairy rupturewort), Prunus avium L. (wild cherry), Rubia tinctorum L. (common madder) and Sempervivum tectorum L. (common houseleek). Numerous Serbian phytotherapeutic literature data describe usage of these plants in treatment of bladder infection as traditional folk remedies, while there are no specific research papers which describe antibacterial effects against $E$. coli, especially on MAR strains (PELAGIC, 2008; TUCAKOV, 2010). Tea is prepared out of these plants and it is a suggested form of remedy according to the folk medicine knowledges. $H$. hirsuta, $R$. tinctorum and $S$. tectorum tea is prepared out of dried leaves, while $P$. avium petiol is used for tea preparation. People from southwestern Serbia and Montenegro often use $S$. tectorum and $H$. hirsuta tea, while $P$. avium and $R$. tinctorum tea is used in eastern and central parts of Serbia, western parts of Bulgaria and northern parts of FYR Macedonia (TUCAKOV, 2010). Considering other parts of Serbia, broadly known and scientifically characterized plants are used for treatment of bladder infections. The aim of this study is to examine the antibacterial effect of following plants (H. hirsuta, P. avium, $R$. tinctorum and $S$. tectorum) which are used in some rural parts of Balkan countries for treatment of bladder infections. Standard bacterial strain used for estimation of the antibacterial effects of these plants is $E$. coli MAR strain isolated from urine of patient with urinary sepsis. Determination of chemical composition was conducted for several compound groups which are considered as main antibacterial agents in these plants.

\section{MATERIAL AND METHODS}

\section{Plant collection and extract preparation}

Plants that were examined for antibacterial activity against $E$. coli MAR strain are: Herniaria hirsuta (hairy rupturewort), (fam. Caryophyllaceae); Prunus avium (wild cherry), (fam. Rosaceae); Rubia tinctorum (common madder), (fam. Rubiaceae) and Sempervivum tectorum (common houseleek), (fam. Crassulaceae). Undamaged healthy plants were collected locally in early summer and identified according to Flora Europaea key for determination of plant species (TUTIN et al. 1969; TUTIN et al. 1976; TUTIN et al. 1993). Freshly collected leaves of $H$. hirsuta, $R$. tinctorum and $S$. tectorum and $P$. avium petioles were air dried in paper bags at 25$28^{\circ} \mathrm{C}$ for 5 days. Leaves and petioles were powdered in a blender and submitted to solvent extractions by maceration with double distilled water and in $70 \%$ ethanol independently at room temperature for 3 days. After the 3-day period of alcohol extraction, the ethanol was evaporated in the exicator. For preparation of both aqueous and ethanol extracts $100 \mathrm{~g}$ of plant material was solved in $100 \mathrm{ml}$ of water and ethanol. Extracts were filtered with Whatman No I filter paper (Whatman Inc ${ }^{\circledR}$, ME, USA) and then the filtrates were collected. Aqueous filtrates were frozen dried and organic filtrates were reduced to residue using a rotary evaporator at $37^{\circ} \mathrm{C}$. Extracts were stored at $-20^{\circ} \mathrm{C}$ until they were used (SAMARTH, 2003).

\section{Isolation of multiple antibiotic resistant $E$. coli strain}

Urine sample was collected from female patient with a positive diagnosis of nosocomial urinary sepsis which came as a result of mistreated bladder infection. All ethical standards were satisfied according to the Helsinki Declaration. After $1 \mathrm{~h}$ of collection, urine sample was immediately inoculated into Luria Bertani (LB) agar plates (Torlak, Belgrade, Serbia). Plates were incubated aerobically at $37^{\circ} \mathrm{C}$ for $18 \mathrm{~h}$ (SAMBROOK, 2001). E. coli was identified using API 20E and 20NE (bio-Mérieux ${ }^{\circledR}$, France) standard kits for identification of enteric bacteria. This strain has been preserved, properly stored and it available for other researchers.

\section{Standard antibiogram assay}

Antibiotic susceptibility test of the isolated E. coli strain against commonly prescribed antibiotics was performed using standard microbiological protocol (BAUER, 1966). The standard antibiotics discs used were those of ampicillin $(10 \mu \mathrm{g})$, ciprofloxacin $(5 \mu \mathrm{g})$, erythromycin $(15 \mu \mathrm{g})$, gentamicin $(10 \mu \mathrm{g})$, 
streptomycin $(10 \mu \mathrm{g})$ and tetracycline $(30 \mu \mathrm{g})$ (Torlak®, Belgrade, Serbia). Standardized overnight culture of $E$. coli isolate (approximately $10^{8}$ $\mathrm{CFU} / \mathrm{ml}$ ) was used to seed melted Mueller Hinton agar (MHA) (Torlak $\AA$, Belgrade, Serbia) at $45^{\circ} \mathrm{C}$ and aseptically poured into sterilized plates and allowed to solidify. The standard antibiotic sensitivity discs were then aseptically placed at reasonable equidistance on the seeded MHA and allowed to stand for $1 \mathrm{~h}$. The plates were then incubated aerobically at $37^{\circ} \mathrm{C}$ for $18 \mathrm{~h}$. The diameters of the growth inhibition zones produced by each antibiotic disc were measured using engineer calipers and the results were interpreted as earlier described as susceptible (s), intermediate resistance (i) or resistant (r) to the antibiotic agent used depending on the length of growth inhibition zones produced compared to reported standard length (NCCLS 1993). Multiple antibiotic resistance (MAR) index (number of antibiotics to which test isolate displayed resistance divided by the total number of antibiotic to which the test organism has been evaluated for sensitivity) for $E$. coli isolate was calculated as recommended (KRUMPERMANN, 1983).

\section{Agar well diffusion method and determination of minimal inhibitory concentration}

In order to determine the antibacterial spectrum, the antibacterial activity was performed by the agar well diffusion method. A volume of 10 $\mathrm{ml}$ of agar medium $(0.7 \% \mathrm{w} / \mathrm{v})$ was inoculated with $0.1 \mathrm{ml}$ of fresh overnight culture of the E. coli strain (approximately $10^{8} \mathrm{CFU} / \mathrm{ml}$ ) and poured into a Petri dish containing layer of the plate count agar (PCA) (Torlak®, Belgrade, Serbia). Wells of $6 \mathrm{~mm}$ in diameter were punched in the agar and filled with $50 \mu \mathrm{l}$ of plant extracts. Ethanol and aqueous extract were applied in seven different concentrations: 0.1 ; $0.25 ; \quad 0.5 ; \quad 1.0 ; \quad 2.5 ; \quad 5.0 ; 10.0 \quad \mathrm{mg} / \mathrm{ml}$. Chloramphenicol (Galenika ${ }^{\circledR}$, Belgrade, Serbia) was used as positive control, while the negative control was formed with autoclaved double distilled water. After holding the plates at room temperature for $2 \mathrm{~h}$ in order to allow diffusion of extracts into agar, the plates were incubated at $37^{\circ} \mathrm{C}$ for $24 \mathrm{~h}$. Then they were examined for inhibition of the bacterial lawn and the diameters of the inhibition zones were measured using engineer calipers (HOOD et al. 2003). The minimal inhibitory concentrations (MICs) were determined as the lowest concentration of plant extracts inhibiting visible growth of each organism on the agar plate (NCCLS 2002). In order to compare the susceptibility of hospital E. coli strain with standard strain, E. coli ATCC 25922 was used and MICs were obtained for ethanol and aqueous extracts.

\section{Determination of total phenolic compounds}

Total phenolic compounds were quantified using the Folin-Ciocalteu assay (MARINOVA et al. 2005). One milliliter of each extract was added to a flask containing $9 \mathrm{ml}$ of distilled water. Then, $1 \mathrm{ml}$ of Folin-Ciocalteu's phenol reagent was added and the mixture was mixed thoroughly. After 5 min, 10 $\mathrm{ml}$ of $7 \%$ sodium carbonate was added. The mixture was diluted to $25 \mathrm{ml}$ with the addition of distilled water and incubated at room temperature for 90 min. Gallic acid (GA) was used as a standard (covering the concentration range between 0.1 and $1.0 \mathrm{mg} / \mathrm{ml}$ ). The absorbance rate was monitored at $\lambda=750 \mathrm{~nm}$ using a spectrophotometer. Total phenolic content was expressed as $\mathrm{mg}$ of $\mathrm{GA} / \mathrm{g}$ of extract.

\section{Determination of total flavonoid concentration}

The aluminum chloride colorimetric method was used for determination of total flavonoid concentration (MARINOVA et al. 2005). One milliliter of each extract was added to a flask containing $4 \mathrm{ml}$ of distilled water. Then, $0.3 \mathrm{ml}$ of $5 \%$ sodium nitrite was added. After $5 \mathrm{~min}, 0.3 \mathrm{ml}$ of $10 \%$ aluminum chloride was added. After $6 \mathrm{~min}$ incubation at room temperature, $2 \mathrm{ml}$ of $1 \mathrm{~mol} / \mathrm{l}$ $\mathrm{NaOH}$ was added. The mixture was diluted to $10 \mathrm{ml}$ with distilled water. The absorbance rate of the solution was measured at $\lambda=510 \mathrm{~nm}$ using a spectrophotometer. Flavonoid concentration was expressed as results were expressed as $\mathrm{mg}$ of catechin equivalents $(\mathrm{CE}) / \mathrm{g}$ of extract.

\section{Determination of total tannin concentration}

Total tannin content was determined by the Folin-Ciocalteu procedure, after removal of tannins by their adsorption on insoluble matrix (polyvinylpolypyrrolidone) (MAKKAR et al. 1993). Calculated values were subtracted from total polyphenol concentration and the total tannin amount was expressed as $\mathrm{mg}$ of $\mathrm{GA} / \mathrm{g}$ of extract.

\section{Determination of anthocyanins concentration}

The quantification of total anthocyanins of plant extracts was spectrophotometrically evaluated by the pH differential method (SHEN et al. 2007). Anthocyanins were extracted with $20 \%$ (vol/vol) ethanol solution at $1: 10$ ratio (wt/wt) at $25^{\circ} \mathrm{C}$ for up to 10 days. Extracts in $5 \mathrm{ml}$ aliquots were diluted either with $0.2 \mathrm{~mol} / 1 \mathrm{KCl}$ and $0.2 \mathrm{~mol} / 1 \mathrm{HCl}(25: 67$ $\mathrm{vol} / \mathrm{vol}$ ) buffer to $100 \mathrm{ml}$ and adjusted to $\mathrm{pH} 1.0$ or with $1.0 \mathrm{~mol} / 1 \mathrm{CH}_{3} \mathrm{COONa}$ and $1.0 \mathrm{~mol} / \mathrm{l} \mathrm{HCl}$ and 
water (10:6:9 by volume) to $50 \mathrm{ml}$ and adjusted to $\mathrm{pH}$ 4.5. These diluted solutions were used for further spectrophotometrical analysis and absorbance was measured at $\lambda=530 \mathrm{~nm}$. The content of total anthocyanins was expressed as $\mathrm{mg}$ of cyanidin 3-glucoside (C3G) equivalents $(\mathrm{C} 3 \mathrm{GE}) / \mathrm{g}$ of extract.

\section{Determination of total saponins concentration}

The total saponins content was determined by the vanillin-sulfuric acid method (CHEN et al. 2010). Extracts were mixed with $8 \%$ vanillin $(\mathrm{w} / \mathrm{v})$ and $72 \%$ sulfuric acid (w/v). The mixtures were incubated at $60^{\circ} \mathrm{C}$ for $10 \mathrm{~min}$ and then cooled on ice water bath for $15 \mathrm{~min}$. Absorbance rate was measured at $\lambda=538 \mathrm{~nm}$ using a spectrophotometer. Quillaja saponin was used as a reference standard and the content of total saponins was expressed as grams of Quillaja saponin equivalents $(\mathrm{QSE}) / \mathrm{g}$ of extract.

\section{Statistical analysis and data management}

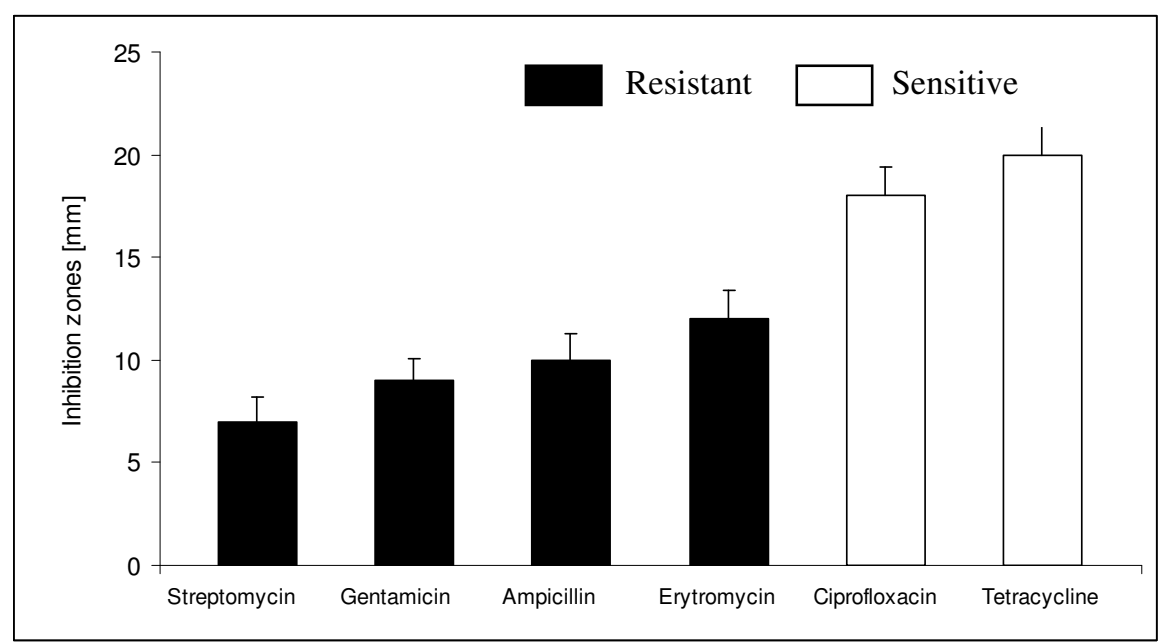

Figure 1. Histogram of inhibition zone diameters obtained after antibiotic susceptibility test of the isolated $E$. coli strain. Six antibiotics were used for testing purposes. This strain is resistant to four antibiotics (black columns) and sensitive to two antibiotics (white columns).

\section{Antibacterial effect of used plants}

Chloramphenicol positive control produced inhibition zone of $34 \pm 2.5 \mathrm{~mm}$ in diameter, while the negative control (double distilled water) did not produce any inhibition zone. The $70 \%$ ethanol negative control produced a $3 \mathrm{~mm}$ wide inhibition zone. The MIC of chloramphenicol is lower than $0.05 \mathrm{mg} / \mathrm{ml}$. Fig. 2 represents the sizes of inhibition zones of $H$. hirsuta, $P$. avium, $R$. tinctorum and $S$. tectorum ethanol and aqueous extracts. Ethanol extracts of $H$. hirsuta and $P$. avium produced larger diameters of growth inhibition zones than theirs aqueous extracts. In contrast, aqueous extracts of $R$.
After four replications, acquired data were expressed as Mean \pm SEM (Arithmetical Mean \pm Standard Error of the Mean). Data distribution was examined using Kolmogorov-Smirnov test. Statistical significance testing was performed by Student's t-test. SPSS 17.0 software package was used for statistical analyses. Differences were considered significant at $\mathrm{p}<0.05$ and highly significant at $\mathrm{p}<0.01$.

\section{RESULTS}

\section{Standard antibiogram assay}

Figure 1 shows diameters of inhibition zones obtained after standard antibiotic susceptibility test of the isolated $E$. coli strain. This strain is resistant to four out of six used antibiotics (ampicillin, erytromycin, gentamicin and streptomycin). MAR index value is 0.67 . Multiple antibiotic resistant $E$. coli strain displayed sensitivity only to ciprofloxacin and tetracycline. 
strain. Also, the lower dose of $P$. avium ethanol and aqueous extract was needed to create growth inhibition than in the case of the hospital strain.
Susceptibility to $R$. tinctorum and $S$. tectorum extracts were identical to those considering hospital E. coli strain.

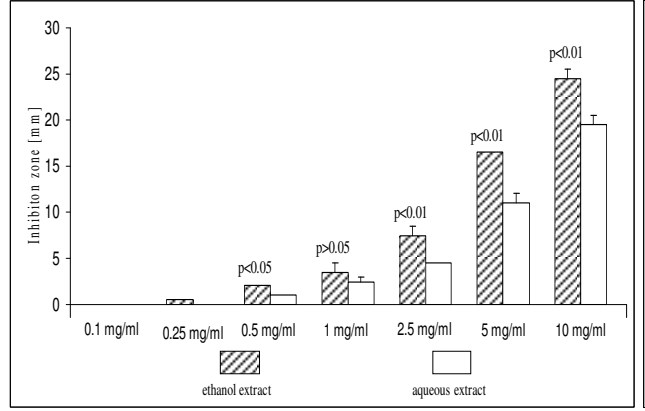

A - Antibacterial effect of Herniaria hirsuta

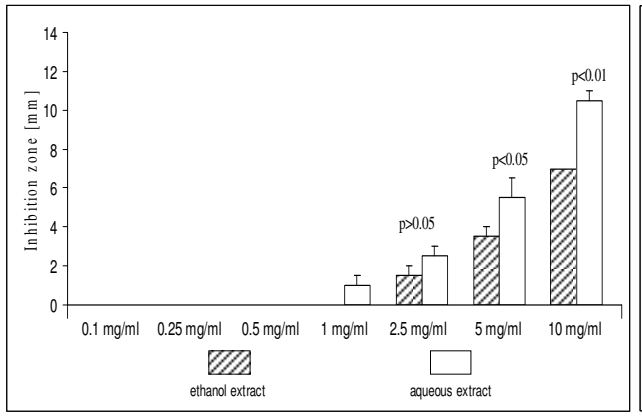

C- Antibacterial effect of Rubia tinctorum

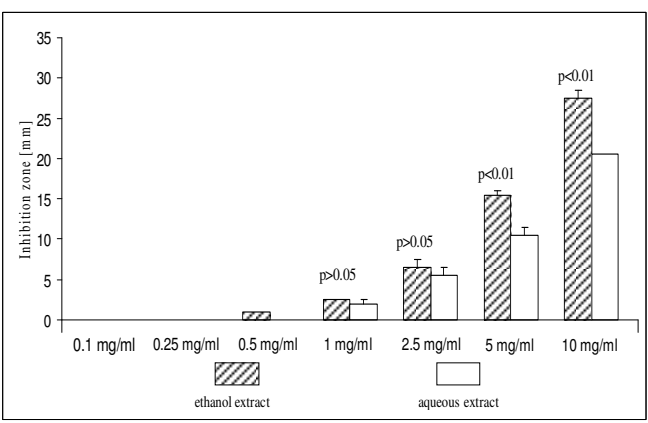

B- Antibacterial effect of Prunus avium

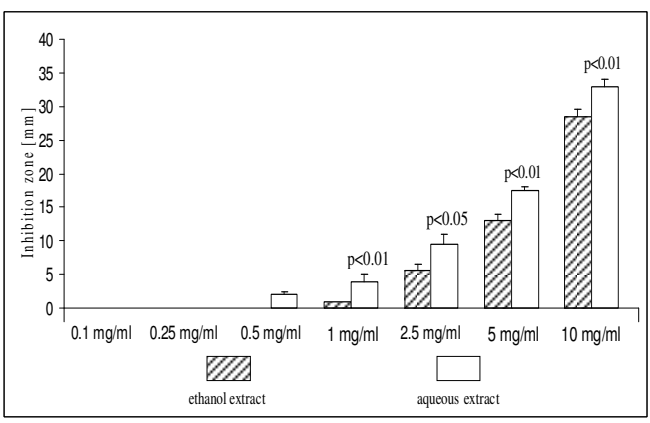

D- Antibacterial effect of Sempervivum tectorum

Figure 2. Shows $E$. coli growth inhibition zones induced with various concentrations of ethanol and aqueous extracts of $H$. hirsuta (A), P. avium (B), R. tinctorum (C) and S. tectorum (D).

Table 1. Results of minimal inhibitory concentrations (MICs) for ethanol and aqueous extracts of each plant evaluated on hospital E. coli strain after four replications. The MICs are represented as $\mu \mathrm{g} / \mathrm{ml}$.

\begin{tabular}{lcc}
\hline \multirow{2}{*}{ Plant } & \multicolumn{2}{c}{ MIC $(\mu \mathrm{g} / \mathrm{ml})$} \\
\cline { 2 - 3 } & Ethanol extract & Aqueous extract \\
\hline Herniaria hirsuta & 250 & 500 \\
Prunus avium & 500 & 500 \\
Rubia tinctorum & 2500 & 1000 \\
Sempervivum & 1000 & 500 \\
tectorum & & \\
\hline
\end{tabular}

Table 2. Results of minimal inhibitory concentrations (MICs) for ethanol and aqueous extracts of each plant evaluated on E. coli ATCC 25922 strain after four replications. The MICs are represented as $\mu \mathrm{g} / \mathrm{ml}$.

\begin{tabular}{lcc}
\multirow{2}{*}{ Plant } & \multicolumn{2}{c}{ MIC $(\mu \mathrm{g} / \mathrm{ml})$} \\
\cline { 2 - 3 } & Ethanol extract & Aqueous extract \\
\hline Herniaria hirsuta & 100 & 250 \\
Prunus avium & 250 & 250 \\
Rubia tinctorum & 1000 & 500 \\
Sempervivum tectorum & 1000 & 500 \\
\hline
\end{tabular}

Biochemical composition of plant extracts 
Amount of total phenolic compounds, flavonoid, tannin, antocyannins and saponins concentration in both ethanol and aqueous extracts is presented in Table 3 .

Table 3. Shows concentrations of phenols, flavonoids, tannins, anthocyanins and saponins in ethanol and aqueous extracts of each plant.

\begin{tabular}{|c|c|c|c|c|c|c|c|c|c|c|}
\hline \multirow[t]{3}{*}{ Plant } & \multicolumn{10}{|c|}{ Compounds } \\
\hline & \multicolumn{2}{|c|}{ Phenols $^{\mathrm{a}}$} & \multicolumn{2}{|c|}{ Flavonoids $^{b}$} & \multicolumn{2}{|c|}{ Tannins $^{\mathrm{a}}$} & \multicolumn{2}{|c|}{ Anthocyanins $^{c}$} & \multicolumn{2}{|c|}{ Saponins $^{\mathrm{d}}$} \\
\hline & $\mathrm{E}$ & A & $\mathrm{E}$ & A & $\mathrm{E}$ & A & $\mathrm{E}$ & A & $\mathrm{E}$ & A \\
\hline Herniaria hirsuta & 28.2 & 22.4 & 4.6 & 3.7 & 12.1 & 8.2 & 3.4 & 3.8 & 16.2 & 8.4 \\
\hline Prunus avium & 23.3 & 20.1 & 3.2 & 2.1 & 3.7 & 3.0 & 1.2 & 1.6 & 6.5 & 2.2 \\
\hline Rubia tinctorum & 14.7 & 18.2 & 1.1 & 1.3 & 6.2 & 7.3 & 0.8 & 0.5 & 2.3 & 0.9 \\
\hline Sempervivum tectorum & 16.0 & 28.5 & 0.9 & 0.6 & 1.2 & 0.8 & 0.7 & 0.5 & 2.0 & 1.1 \\
\hline
\end{tabular}

\section{DISCUSSION}

Antibiotic therapy usually provides effective treatment of bacterial infections but there is an increasing problem of antibiotic resistance and a continuing need for new solutions. The management of bacterial infection became complicated because of the emergence of resistance to most first-line antimicrobial agents (VACHEVA et al. 2012). Many people prefer to use herbal remedies rather than antibiotics especially those herbal medicines which are often used in traditional medicine (MARTIN, 2003; LITTLE, 2009). Hundreds of plants are used worldwide for treatment of bacterial infections, however not all of them are subjected to in vitro studies and clinical trials. Many reports describe the antibacterial activity of plant's crude extracts that inhibit growth of various bacteria but there are a limited number of in vitro antimicrobial studies and it has not been determined whether they are superior, equivalent or inferior to antibiotics (DAWSON, 2005; PAGM, 2002). Several studies have proven that $E$. coli isolates with MAR phenotypes, involving co-resistance to four or more unrelated families of antibiotics have been previously reported and considered as an emerging public health issue (VENTURINI et al. 2010). Since bladder infection is a common disease and most frequently caused by $E$. coli, this study's aim was to examine the antibacterial activity of traditionally used plants in Serbia and other Balkan countries for bladder infection. Standard antibiogram assay showed that $E$. coli isolate is a MAR strain (MAR index=0.67). This strain was intentionally used, because there is an increasing tendency of MAR strains among hospital isolates and according to that, a new therapeutic approach is needed. Knowledge and practice of traditional medicine offer such approach only if it is well characterized by numerous in vitro and in vivo studies. According to scientific literature and national pharmacognosy experts, four plants are mostly used for treatment of bacterial infections in Serbia: $H$. hirsuta (hairy rupturewort), $P$. avium (wild cherry), $R$. tinctorum (common madder) and $S$. tectorum (common houseleek). (KOJIC et al. 1998; PELAGIC, 2008; TUCAKOV, 2010). H. hirsuta belongs to Caryophyllaceae family which is not enough examined for antibacterial components regarding isolation and estimation of specific substances. However, antibacterial properties of Caryophyllus aromaticus, which is a member of the same family, are well known and characterized. Eugenol and isoeugenol are two main phenolic compounds which are responsible for most of antibacterial activity (YADAV et al. 2011). Antibacterial effect against MAR E. coli strain was demonstrated in vitro, using agar the dilution method. The ethanol extract produced significantly higher values of inhibition zones than aqueous extract. MIC was lower for ethanol than for aqueous extract considering both MAR and referent strain. There are higher amounts of all examined compounds in ethanol than in aqueous extract which is in a direct relation to its superior antibacterial property. $P$. avium is a member of the Rosaceae family whose member species are described with antibacterial potential in several studies (BELLA CRUZ et al. 2006; NIKITINA et al. 2007). The antibacterial effect of $P$. avium petiole extract is proven in vitro for the first time in this study. Ethanol extract shows higher values than aqueous extract, and MIC is lower for ethanol than for aqueous extract when both strains are compared. High concentrations of phenols and flavonoids in ethanol extract can explain the potent antibacterial effect. $R$. tinctorum is a part of the Rubiaceae family and it is known as rich with antraquinone which is used as antiinflammatory, 
antimicrobial, antibacterial and antidiuretic drug (SWAIN, 1996). Considering antraquinone from $R$. tinctorum, which is denoted as a main antibacterial compound, it is necessary to stress that antraquinone is poorly soluble in water as well as in ethanol on temperatures lower than boiling point (VOGEL, 2002). Therefore, it implies that antraquinone is not responsible for antibacterial effect of $R$. tinctorum on MAR E. coli strain because it is not solved in water neither ethanol. Previous studies demonstrated antibacterial effect of $R$. tinctorum on some pathogenic bacteria, but not on E. coli (CALIS et al. 2009). Aqueous extract of $R$. tinctorum developed higher inhibition zones than ethanol extract and therefore MIC of aqueous extract is lower for both examined strains. It can be noticed that aqueous extract has higher amounts of phenols, flavonoids and tannins than ethanol extract, which is in a direct relation to its stronger antibacterial effect. Polyphenols isolated from leaves of S. tectorum which belongs to Crassulaceae family are marked as principal agents responsible for antibacterial effects (ABRAM, 1999). Aqueous extract of S. tectorum showed stronger antibacterial activity than ethanol extract against E. coli MAR strain and E.coli referent strain. Due to the highly polar chemical properties, notably higher amount of phenols is present in aqueous than in ethanol extract, which corresponds with their higher antibacterial activity. The antibacterial properties of polyphenols lies on the potential to oxidate and/or hydrolize the bacterial cell wall and plasma membrane (TAGURI et al. 2004). Crude solvent plant extracts are to be considered as potentially therapeutically useful if they have MIC values lower than $8 \mathrm{mg} / \mathrm{ml}$, while isolated phytochemicals should have MICs lower than $1 \mathrm{mg} / \mathrm{ml}$ (GIBBONS, 2005). All examined plants displayed antibacterial activity and their MICs are lower than $8 \mathrm{mg} / \mathrm{ml}$. Taken collectively, individual extracts display richness in certain classes of examined compounds which corresponds with its antibacterial activity, but it is necessary to stress that all compounds act synergistically against bacteria according to their amount and chemical relation with other substances. The antibacterial effect of each compound mentioned in this study can be evaluated only if they are isolated and examined separately. It is necessary to conduct more sophisticated analytical studies of chemical composition of used plant extracts, which would lead to a potential identification of other antibacterial compounds. The antibacterial effect of traditionally used plants in Serbia for bladder infection should be examined for other bacteria that cause this pathological state, like Proteus spp., Klebsiella spp. and Pseudomonas aeruginosa. We propose a multicentric study that would examine the effectiveness of traditional plant remedies for E. coli based urinary infections from different countries. After in vitro antibacterial study, it has been confirmed that tea from most commonly used traditional plants in rural parts of the Balkans has significant antibacterial effect on MAR E. coli strain. Teas made out of these plants should be considered for some of the future clinical studies, which could prove its efficiency in the randomized groups of patients suffering from UTI caused by worldwide emerging MAR strains. Health professionals should be aware of the available evidences for herbs with antibacterial effects, especially of those plants which are present in their country and which are used traditionally for ages. Because all four plant species examined in this study are cosmopolitan species, the application of traditional knowledge of Balkan countries can be applied in many other countries as additional therapy for $E$. coli based urinary infections. The extracts of analyzed plants, above all $\mathrm{H}$. hirsuta and $P$. avium should be considered as adjuvant antibacterial agents, because they are available in most of the countries and because of their evidently benevolent use in form of tea and tincture which if confirmed by experience of many generations. Herbal medicine will surely be a point of interest in the forthcoming period worldwide dissemination of MAR strains.

RESUMO: O surgimento de Escherichia coli isoladas com vários fenótipos resistentes aos antibióticos é considerado como um grave problema de saúde. No presente trabalho o efeito antibacteriano das seguintes plantas (Herniaria hirsuta, Prunus avium, Rubia tinctorum e Sempervivum tectorum) foi analisado. O agente bacteriano modelo utilizado para estimativa de susceptibilidade bacteriana é o hospital vários resistentes a antibióticos E. coli. E. coli ATCC 25922 padrão foi utilizado para comparação de antibiogramas. Folhas de H. hirsuta, R. tinctorum e S. tectorum bem como pecíolos de P. avium foram coletados. Etanol e extrato aquoso de cada planta foi preparado. Atividade antibacteriana foi analisada através do método de difusão em ágar-bem. Total Concentração de fenóis, flavonóides, taninos e saponinas antocyanins determinou-se em extratos de plantas. E. coli estirpe é resistente às quatro famílias de antibióticos independentes. Efeito antibacteriano é comprovado para todas as plantas examinadas. Os extratos etanólicos de H. hirsuta e P. avium têm um efeito mais potente antibacteriano de seus extratos aquosos. Extratos aquosos de R. tinctorum e S. tectorum têm maior potencial antibacteriano que os extratos etanólicos. Extratos vegetais examinados representam bons 
candidatos para pesquisa mais ampla em vista de sua aplicação no tratamento de vários antibióticos resistentes a cepas de E. coli.

PALAVRAS-CHAVE: Resistência aos antibióticos. Escherichia coli. Medicina Tradicional. Extratos de plantas. Compostos com atividade antibacteriana.

\section{REFERENCES}

ABRAM, V.; DONKO, M. Tentative identification of polyphenols in Sempervivum tectorum and assessment of the antimicrobial activity of Sempervivum L. J. Agric. Food. Chem., v. 47, p. 485-489, 1999.

http://dx.doi.org/10.1021/jf980669d

BAUER, A.; KIRBY, W.; SHERRIS, J.; TURCK, M. Antibiotics susceptibility testing by a standardized singles disc method. Am. J. Clin. Pathol., v. 45, p. 493-496, 1966.

BELLA CRUZ, A.; BELLA CRUZ, R.; KANEGUSUKU, M.; CECHINEL FILHO, V.; YUNES, A.; DELLE MONACHE, F.; NIERO, R. Antimicrobial activity of Rubus imperialis (Rosaceae). Acta. Farm. Bonaerense., v. 25, p. 256-259, 2006.

CALIS, A.; CELIK, Y.; KATIRCIOGLU, H. Antimicrobial effect of natural dyes on some pathogenic bacteria. Afr. J. Biotechnol., v. 8, p. 291-293, 2009.

CHEN, Y. F.; YANG, C. H.; CHANG, M. S.; CIOU, Y. P.; HUANG, Y. C. Foam properties and detergent abilities of the saponins from Camellia oleifera. Int. J. Mol. Sci., v. 11, p. 4417-4425, 2010.

http://dx.doi.org/10.3390/ijms11114417

DAWSON, W. Herbal medicine and the EU directive. J. R. Coll. Physicians. Edinb., v. 35, p. 25-27, 2005.

GIBBONS, S. Plants as a source of bacterial resistance modulators and anti-infective agents. Phytochem. Rev., v. 4, p. 63-78, 2005. http://dx.doi.org/10.1007/s11101-005-2494-9

HOOD, J.; WILKINSON, J.; CAVANAGH, H. Evaluation of common antibacterial screening methods utilized in essential oil research. J. Essent. Oil. Res., v. 15, p. 428-433, 2003.

http://dx.doi.org/10.1080/10412905.2003.9698631

KOJIĆ, Momčilo; STAMENKOVIĆ, Vlastimir; JOVANOVIĆ, Dušan. Herbal medicines of southeastern Serbia. 1st ed. Belgrade: Zavod za udžbenike u nastavna sredstva, 1998. 168 p.

KRUMPERMANN, P. Multiple antibiotics resistance indexing of $E$. coli to identify high risks sources of fecal contamination of foods. Appl. Environ. Microbiol., v. 46, p. 165-170, 1983.

LITTLE, C. Simply because it works better: exploring motives for the use of medical herbalism in contemporary U.K. health care. Complement. Ther. Med., v. 17, p. 300-308, 2009.

http://dx.doi.org/10.1016/j.ctim.2009.08.001

MAKKAR, H. P. S.; BLUEMMEL, M.; BOROWY, N. K.; BECKER, K. Gravimetric determination of tannins and their correlations with chemical and protein precipitation methods. J. Sci. Food. Agric., v. 61, p. 161-165, 1993. http://dx.doi.org/10.1002/jsfa.2740610205

MARINOVA, D.; RIBAROVA, F.; ATANASSOVA, M. Total phenolics and total flavonoids in Bulgarian fruits and vegetables. J. Univ. Chem. Technol. Metall., v. 40, p. 255-260, 2005.

MARTIN, K.; ERNST, E. Herbal medicines for treatment of bacterial infections: a review of controlled clinical trials. J. Antimicrob. Chemother., v. 51, p. 241-246, 2003. http://dx.doi.org/10.1093/jac/dkg087 
National Committee for Clinical Laboratory Standards (NCCLS). Performance standards for antimicrobial disk susceptibility tests: Approved Standard M2-A5, NCCLS, Villanova, PA, 1993.

National Committee for Clinical Laboratory Standards (NCCLS). Performance standards for antimicrobial susceptibility testing: Twelfth Informational Supplement M100-S12, NCCLS, Wayne, PA, 2002.

NIKITINA, V.; KUZMINA, L.; MELENTEV, A.; SHENDEL, G. Antibacterial activity of polyphenolic compounds isolated from plants of Geraniaceae and Rosaceae families. Prikl. Biokhim. Mikrobiol., v. 43, p. 705-712, 2007. http://dx.doi.org/10.1134/s0003683807060117

PAGM, D. Herbal remedies. N. Engl. J. Med., v. 347, p. 2046-2056, 2002.

http://dx.doi.org/10.1056/NEJMra020398

PELAGIĆ, V. Pelagic`s folk teacher. 2nd ed. Belgrade: Beoknjiga, 2008. 420 p.

SAMARTH, R.; KUMAR, A. Radioprotection of Swiss albino mice by plant extract Mentha piperita (Linn.). J. Radiat. Res., v. 44, p. 101-109, 2003. http://dx.doi.org/10.1269/jrr.44.101

SAMBROOK, J.; RUSSELL, D. Molecular cloning - a laboratory manual, 3rd ed. Cold Spring Harbor: Cold Spring Harbor Laboratory Press, 2001. 11.62 p.

SHEN, S. C.; TSENG, K. C.; CHAO, F. T.; WU, S. B. Color quality of rose liquer. J. Food. Qual., v. 30, p. 202-217, 2007. http://dx.doi.org/10.1111/j.1745-4557.2007.00115.x

SWAIN, T. Comparative phytochemistry. New York: Academic Press, 1996. 245 p.

TAGURI, T.; TANAKA, T.; KOUNO, I. Antimicrobial activity of 10 different plant polyphenols against bacteria causing food-born disease. Biol.Pharm.Bull., v. 27, p. 1965-1969, 2004.

http://dx.doi.org/10.1248/bpb.27.1965

TUCAKOV, J. Phytotherapy. 1st ed. Belgrade: Zapis, 2010. 515 p.

TUTIN, T. G; BURGES, N. A; CHATER, A. O; EDMONDSON, J. R; HEYWOOD, V. H; MOORE, D. M; VALENTINE, D. H; WALTERS, S. M; WEBB, D. A. Flora Europaea. Vol. 1. Cambridge: Cambridge University Press, 1993.

TUTIN, T. G; HEYWOOD, V. H; BURGES, N. A; MOORE, D. M; VALENTINE, D. H; WALTERS, S. M; WEBB, D. A. Flora Europaea, Vol. 2. Cambridge: Cambridge University Press, 1969.

TUTIN, T. G; HEYWOOD, V. H; BURGES, N. A; VALENTINE, H. D. Flora Europaea. Vol. 4. Cambridge: Cambridge University Press, 1976.

VACHEVA, A.; GEORGIEVA, R.; DANOVA, S.; MIHOVA, R.; MARHOVA, M.; KOSTADINOVA, S.; VASILEVA, S.; BIVOLARSKA, M.; STOITSOVA, S.R. Modulation of Escherichia coli biofilm growth by cell-free spent cultures from lactobacilli. Cent. Eur. J. Biol., v. 7, p. 219-229, 2012.

http://dx.doi.org/10.2478/s11535-012-0004-9

TRINCHINA, E. V. Structural and functional study of the receptor binding site for FimH adhesin in uropathogenic strains of Escherichia coli. Bull. Exp. Biol. Med., v. 136, p. 380-384, 2003.

http://dx.doi.org/10.1023/B:BEBM.0000010958.02737.e7

VENTURINI, C.; BEATSON, S.; ĐORĐEVIĆ, S.; WALKER, M. Multiple antibiotic resistance gene recruitment onto the enterohemorrhagic Escherichia coli virulence plasmid. FASEB. J., v. 24, p. 1160-1163, 2010. http://dx.doi.org/10.1096/fj.09-144972 
CHESNOKOVA, V. L.; KRAVTSOV, E. G.; SOKURENKO, E. V. Escherichia coli M17: analysis of the adhesive phenotype as a factor of the microorganism colonization and/or pathogenicity. Biull. Eksp. Biol. Med., v. 127, p. 424-428, 1999. http://dx.doi.org/10.1007/BF02433388

VOGEL, A. Anthraquinone. In: Ullmann's Encyclopedia of Industrial Chemistry. 6th ed. Weinheim: WileyVCH, 2002, p. 132.

WILLFORT, R. Herbal medicines and their utilization. 1st ed. Belgrade: Sezam book, 2009. 328 p.

WOODFORD, N.; REDDY, S.; FAGAN, E. J.; HILL, R. L.; HOPKINS, K. L.; KAUFMANN, M. E.; KISTLER, J.; PALEPOU, M. F.; PIKE, R.; WARD, M. E.; CHEESBROUGH, J.; LIVERMORE, D. M. Wide geographic spread of diverse acquired AmpC beta-lactamases among Escherichia coli and Klebsiella spp. in the UK and Ireland. J. Antimicrob. Chemother., v. 59, p. 102-105, 2007. http://dx.doi.org/10.1093/jac/dk1456

YADAV, J.; KUMAR, P.; CHAUDHARY, H. S.; JAIN, M.; GOEL, A. K.; SWAMI, A. K. The antibacterial potency of Caryophyllus aromaticus extracts against methicillin resistant Staphylococcus aureus. J. Pharm. Res., v. 4, p. 3819-3820, 2011. 